\title{
Assessment of Prevalence and Psychosocial behaviour of Tobacco Addictive School going Children with Awareness for Deaddiction
}

\author{
Research Article
}

\section{Prachi Kishor Gulhane ${ }^{1}$, Renu B Rathi2 ${ }^{*}$, Bharat Rathi ${ }^{3}$}

1. Scholar, 2. Professor, Department of Kaumarbhrutya, 3. Professor, Department of Rasashastra Bhaishjya Kalpana, Mahatma Gandhi Ayurveda College and Research Centre, Salod. Maharashtra. India

\begin{abstract}
Background: Tobacco addiction is an emerging as a big threat among children in developing countries and it is increasing day by day. Tobacco use is the world's leading cause of death, accounting for 4.9 million deaths per year. Tobacco is addictive in all forms and causes behavioural changes and it increases the risk of cancer, heart attack, stroke, peripheral vascular disease, osteoporosis, chronic obstructive pulmonary disease, diabetes and adverse reproductive outcomes. So, it is necessary to find out addiction prevalence, problems and highlights possible role of Ayurvedic principles. Aim: To assess the prevalence and psychosocial behaviour of tobacco addictive school going children with awareness for deaddiction. Method: Study was conducted on 300 school students of age group 6 years to 16 years of Z.P. schools of Sawangi and Salod, Wardha, Maharashtra. Study was grounded on WHO Questionnaire Based Survey. Observation: Out of the 300 students, all 109 children-36\% were taking smokeless tobacco in different forms and no one was taking smoke tobacco in the form of Bidi or Cigarettes. They were educated with hazardous effects of tobacco and counselled for deaddiction. Stopping sales of tobacco to children would be an important step. Conclusion: Prevalence of tobacco addiction-36\% with 67\% impact on psycho-social behavioral was observed which is much higher. They were fell apart from non-addictive students due to strong aroma of these products, also not actively taking part in other school activities due to lack of interest. The habit- forming impact was so aggravated that $82 \%$ students were tried to give-up this habit but not succeeded, therefore, anti-tobacco educational sessions for parents, teachers and students were taken by audio-visual power point presentation.
\end{abstract}

Key Words: Tobacco addiction, Deaddiction, Psycho-social behaviour, Prevalence, ZP school children, Wardha.

\section{Introduction}

The epidemic of tobacco use is shifting from developed to developing countries, including India. Tobacco use in smoke and smokeless form, both are major public health issues in developing countries. World Health Organization (WHO) estimates that annually 4.9 million deaths are attributable to tobacco addiction. This is expected to rise of 4 million deaths per annum occurring in India (1). $90 \%$ of the oral cancers in South East Asia Region are linked to tobacco chewing and tobacco smoking (2). Currently in India, more than 8 lakh people die and 12 million become ill as a result of tobacco use every single year. An estimated 186 million of the world population are school children of 13-15 years. Among them, approximately 34.8 million are current tobacco users (3). It is estimated that 5500 adolescents start using tobacco each day in India, joining the 4 million under 15 years who are regularly using tobacco. $40 \%$ of the

\section{* Corresponding Author:}

\section{Renu B Rathi}

Professor, Department of Kaumarbhrutya, Mahatma Gandhi Ayurveda College and Research Centre, Salod; Datta Meghe University of Medical Sciences,

Sawangi, Wardha

Email Id: rbr.226@gmail.com tobacco consumed in India is in the smokeless form like Pan, Pan masala, khaini, Gutka, kharra etc (4).

As per WHO, addiction means the fact or process of being addicted [dependent on as a habit; unable to do without a thing], especially the condition of taking a drug habitually and being unable to give it up without incurring adverse effects (5). The prevention of tobacco use in young people appears as the single greatest opportunity for preventing non-communicable diseases in the world today (6). There is an urgent need for good, scientifically sound data about tobacco use pattern to design preventive strategies and aware them about its hazards and de-addiction.

The main cause is depraved peer group. Parents use to send their child to purchase tobacco products for them and do eat in front of them. These environmental factors compel them to try it once and later again and again to easily become an addict. Tobacco is the main entryway of all other drugs (7). Among the youth, late adolescents belonging to 16 years age group are particularly vulnerable due to increasing academic pressures, encouragement by peers, lure of popularity and easy availability. Early initiation of substance abuse is usually associated with a poor prognosis and a lifelong pattern of deceit and irresponsible behavior (8). This survey was aimed at assess prevalence and psychosocial behavior of addictive students of Zilla Parishad schools of Salod and Sawangi area of Wardha, Maharashtra. 
Prachi Kishor Gulhane et.al., Assessment of Prevalence and Psychosocial behaviour of Tobacco Addictive Children

Material and Methods

Survey was started after getting IEC approval (Sept 2019/8455)

\section{Place of the study}

Maharashtra

Z.P. Schools of Salod and Sawangi, Wardha,

Study design

Observational-Survey based study

Sample size of the study

300 children of 6-16 years age group.

\section{Duration}

6 months

\section{Inclusion criteria}

- The children in schools who had habit of tobacco use in gutka or other smoke less form were-included irrespective of their gender, socio-economic status, caste and religion.

- Children who gave accent or teachers/parents willing to give consent for this survey study.

\section{Methods}

The present study was a survey undertaken among school children in ZP schools of Sawangi and Salod, Wardha with objectives of assessment of prevalence of psychosocial behavior of Tobacco addictive children. Also, finding out psychosocial impact of accepting the addictions in early ages with reasons. The study population comprised of all students studying in class $1^{\text {st }}$ to $10^{\text {th }}$ Std. The survey was conducted using Tobacco Questionnaire (9-11) revalidated and based on WHO guidelines. This survey was about psychosocial behavior of tobacco additive children. The school authorities, class teachers and students were given a brief introduction of survey, the aim and method of giving responses. Data collected from survey by fill-up of questionnaire and documented. Then students were informed regarding side effects of tobacco chewing and suggestions were given. As per questionnaire, total 8 questions were asked related to tobacco addiction or tobacco use, details have been given in observation and results. The researcher was briefed to students/respondents that they should reply the answers on what they really do and what really happen with them. They were also told that there was no right or wrong questions and no concern with their study/exam/marks to avoid any bias.

Thus, collected data was analyzed by using suitable graph, diagrams and tables.

\section{Observations and result}

Total number of students studied in sample was 300. There were 3 schools, having 165, 85, and 50 students respectively. The distribution of students based on their gender, age, education, religion, type of family, socio-economic status, all these are shown in Table number 1 to 6 respectively.
Table 1: Distribution of study population as per gender

\begin{tabular}{|c|c|c|}
\hline Gender & $\begin{array}{c}\text { No. of children } \\
\text { out of } 300\end{array}$ & Percentage \\
\hline Male & 150 & $50 \%$ \\
\hline Female & 150 & $50 \%$ \\
\hline
\end{tabular}

Table 2: Distribution of study population as per age group

\begin{tabular}{|c|r|r|}
\hline Age Group & $\begin{array}{c}\text { No. of children } \\
\text { out of } 300\end{array}$ & \multicolumn{1}{|c|}{ Percentage } \\
\hline 6-11 years & 166 & $56 \%$ \\
\hline $12-16$ years & 134 & $44 \%$ \\
\hline
\end{tabular}

Table no.3: Distribution of study population as per education

\begin{tabular}{|c|c|c|}
\hline Education & $\begin{array}{c}\text { No. of children } \\
\text { out of } 300\end{array}$ & Percentage \\
\hline Primary & 159 & $53 \%$ \\
\hline Middle & 98 & $33 \%$ \\
\hline Secondary & 43 & $14 \%$ \\
\hline
\end{tabular}

There were same number of girls and boys. While there were $56 \%$ and $44 \%$ of age group laid between 6-11years and 12-16 years respectively. Maximum numbers of children-53\% were taking primary education while $33 \%$ and $14 \%$ of children were receiving secondary and higher secondary education.

Table no. 4: Distribution of children as per religion

\begin{tabular}{|c|c|c|}
\hline Religion & $\begin{array}{c}\text { No. of students } \\
\text { out of } 300\end{array}$ & Percentage \\
\hline Hindu & 231 & $77 \%$ \\
\hline Muslim & 5 & $2 \%$ \\
\hline Buddhist & 47 & $15 \%$ \\
\hline Sindhi & 17 & $6 \%$ \\
\hline
\end{tabular}

There were 231 Hindu, 5 Muslim, 47 Buddhist and 17 Sindhi out of 300 children from all the 3 Z.P. schools. Out of 300 children, 232 children were belonging to nuclear family and remaining 68 children belonged to joint family (table no. 5). Most of the children have lower economic status i.e. 191 out of 300 and 109 children from lower-middle class status (table no. 6).

\section{Table no. 5: Distribution of children as per type of family}

\begin{tabular}{|c|c|c|}
\hline Type of family & $\begin{array}{c}\text { No. of students } \\
\text { out of } 300\end{array}$ & Percentage \\
\hline Nuclear & 232 & $77 \%$ \\
\hline Joint & 68 & $23 \%$ \\
\hline
\end{tabular}

Table no. 6: Distribution of children as per socioeconomic class

\begin{tabular}{|c|c|c|}
$\begin{array}{c}\text { Socio-economic } \\
\text { class }\end{array}$ & $\begin{array}{c}\text { No. of students } \\
\text { out of } 300\end{array}$ & Percentage \\
\hline Poor class & 191 & $64 \%$ \\
\hline $\begin{array}{c}\text { Lower-Middle } \\
\text { class }\end{array}$ & 109 & $36 \%$ \\
\hline
\end{tabular}


Students were asked if they consumed tobacco or not. If they use to consume then the form of tobacco was asked. There are different forms of smokeless tobacco available in the market. The data of children is shown in graph A.

Out of 300 students, all 109 students were found as smokeless tobacco addictive (36\%) while no one was taking in smoke form and tobacco was not consumed by $191(64 \%)$ students. (Diagram 1)

\section{Diagram 1 : Total tobacco addictive children}

\section{Tobacco Addictive}

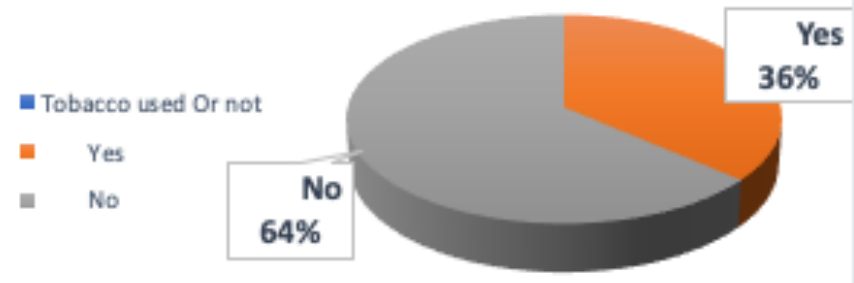

Out of 109 addictive students, 58 had habit of consumption of smokeless supari pouch. 3 were addicted for consumption of Kharra, while $8 \& 15$ students were habitual for pan masala and Gutka consumption respectively. 12 students had craved for tobacco and 13 students were used to consume more than one tobacco products like supari \& tobacco both. Percentage of this study is as shown in Graph A.

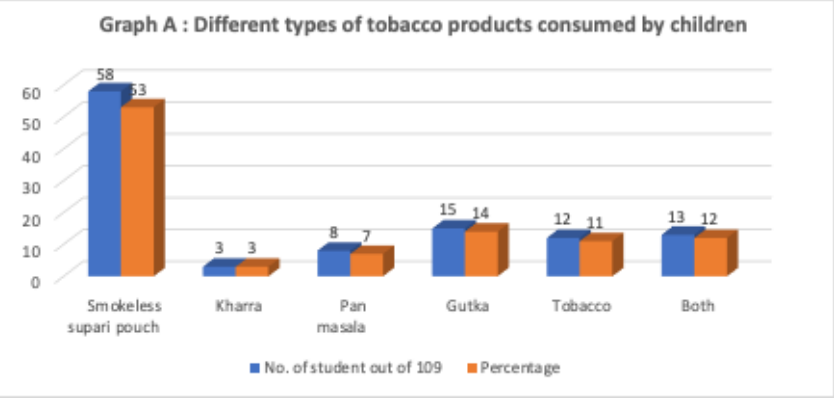

Frequency of tobacco use and its craving in tobacco addictive children were also studied. The observation of study is depicted in Graph B

Graph B : Frequency of tobacco chewing

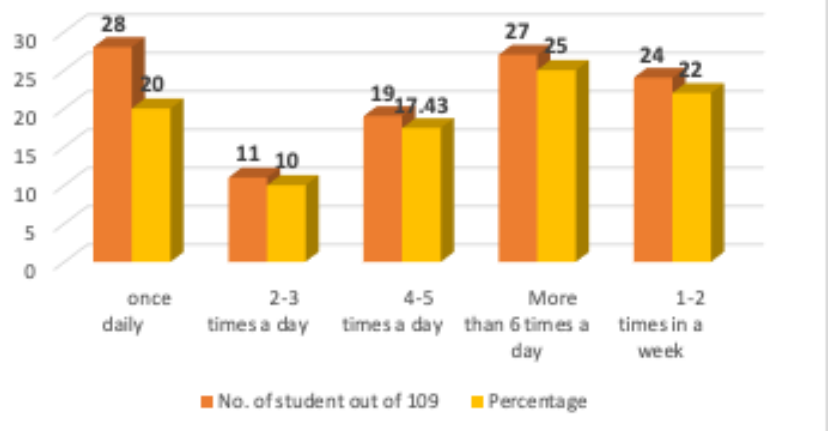

There were total 85 students who were consuming tobacco regularly. Out of which 28 students were consuming tobacco daily once. 11 of them were consuming tobacco 2-3 times a day. 19 students were used to consume tobacco 4-5 times a day. 27 students had craved so that they were consuming it more than 6 times a day while 24 students were consuming smokeless tobacco products 1-2 times in a week.

As per survey, the first question was asked to tobacco addictive children, "did they have strong and irresistible urge to use tobacco?" and answers were noted. All 109 students answered and accepted positively that they were consuming it. (Diagram 2)

\section{Diagram 2-strong urge}

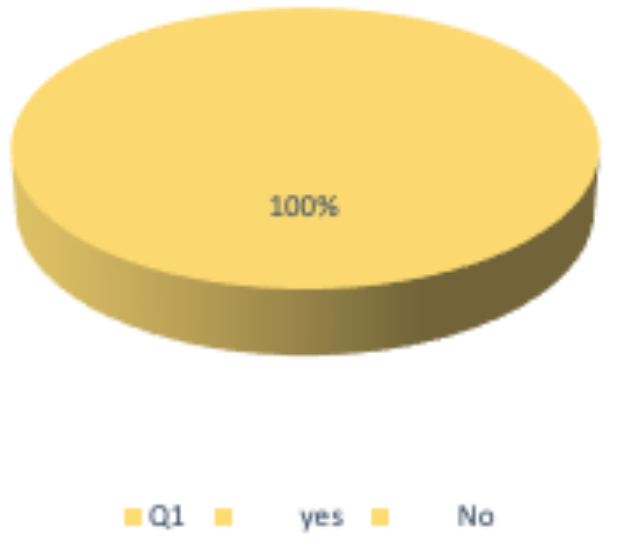

The second question was asked that "did they have emotional symptoms when they stopped using tobacco?" and their perspective answers were noted. The data of this question is as shown in Graph C.

\section{Graph C-Emotional disturbances}

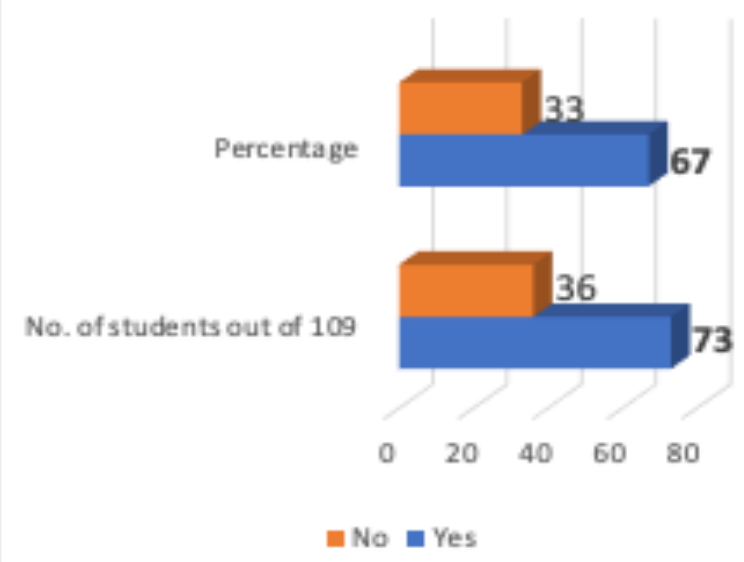

Out of 109 students who were addictive for tobacco chewing, 73 had emotional symptoms like irritability, nervousness, restlessness, trouble in concentrating. While 36 out of them did not have any symptoms.

Question third was "did they use tobacco to prevent from feeling physical and emotional problems or not?" The data of this question is as shown in Graph D. 


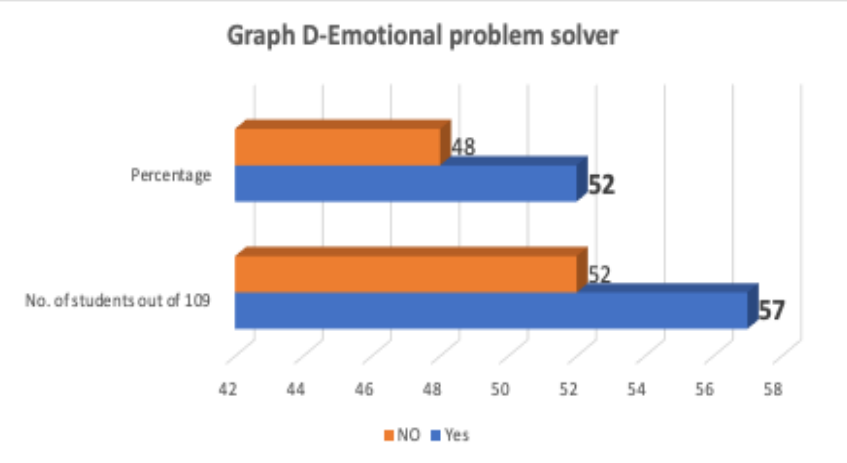

Out of 109 students, who were addicted to tobacco, 57 consumed tobacco to prevent physical and emotional problems and 52 students were not consuming tobacco to prevent.

The question fourth was asked, "did they use tobacco even though they had promised themselves they would not?" and their answers were noted. The perception of this question is as shown below in Graph E

Graph E-Fail to keep promises

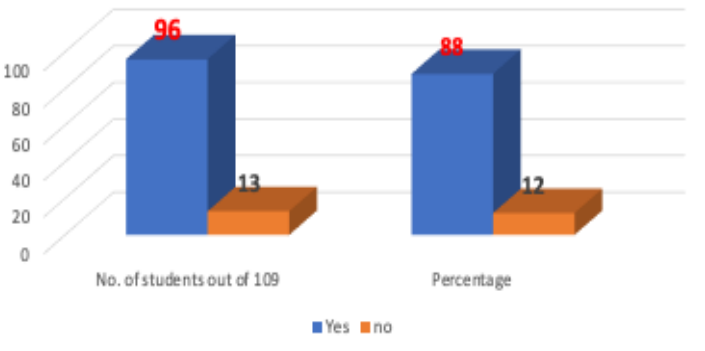

Out of 109, 96 students answered positively that means they failed to keep their promises that they would not consume tobacco anymore. And there was nothing like that in cases of remaining 13 students out of 109 .

Next question "was there any time when they consumed tobacco more frequently or more times a day than they intended?" The answers of this question were noted and shown in Graph $\mathrm{F}$ in percentage.

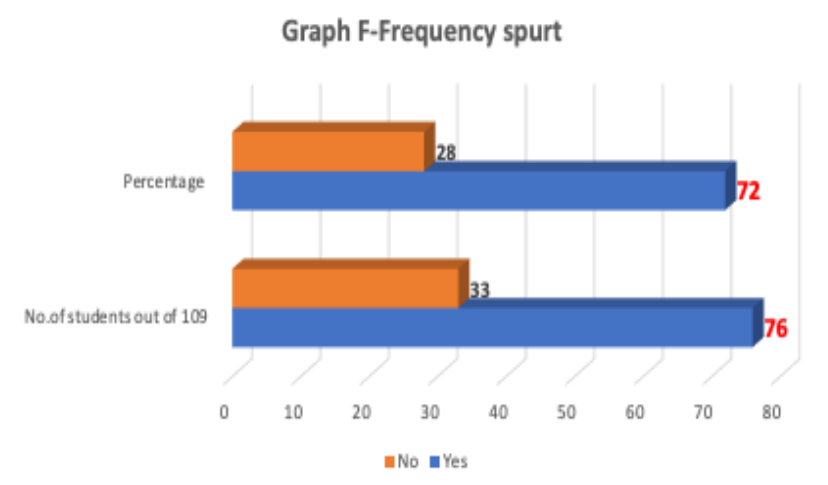

Out of 109, 76 students were consumed tobacco more frequently than they intended and 33 students did not consume tobacco frequently.

Sixth question was asked, "were there times when they tried to stop or cut down their smokeless tobacco consumption?" and found that they were not able to do so, depicted in Graph G.
Graph G -Failure to quit

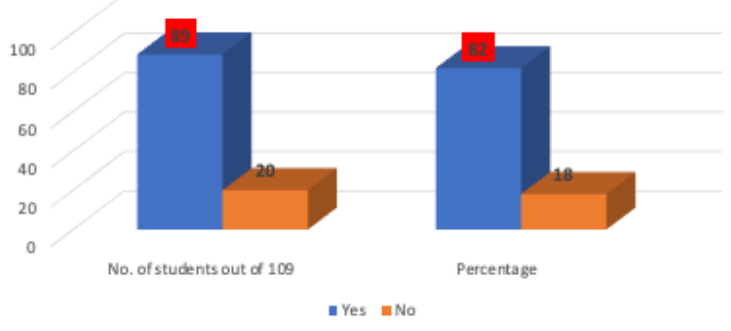

Out of 109 , it is noticed that 89 students tried to stop or cut out their habit but they failed. But in cases of remaining 20 students never tried to give-up their habit.

Seventh question asked to children was, "did they had periods when they consumed tobacco products in smokeless form for several days or more?" The answers of this question from tobacco addictive children were noted. The observation is shown in graph $\mathrm{H}$.

Graph H-duration of habit spurt

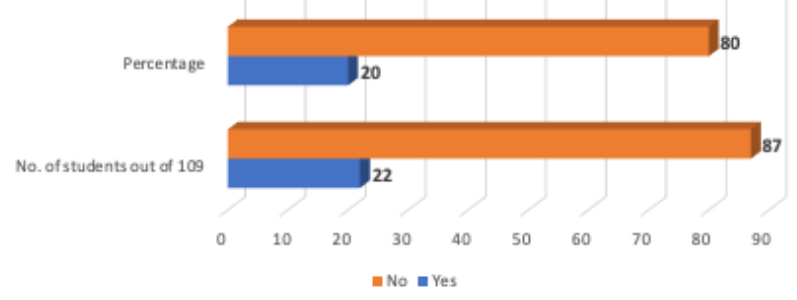

There were 22 students who had periods when they consumed it for several days or more while 87 students had not such complaint.

The last question i.e eighth question asked was, "did they give up or reduced important activities so they could use tobacco?" The answers of this question by 109 students were noted. They are as depicted in Graph I.

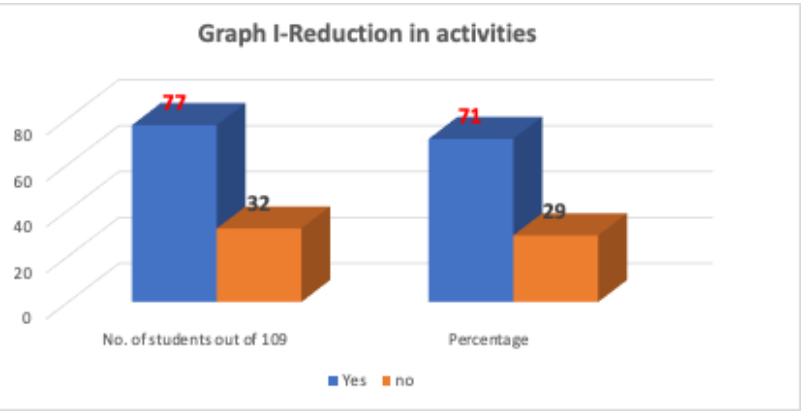

It is noted that 77 students out of 109 were reduced their activities so they could use tobacco and 32 did not reduce their activities for tobacco use.

\section{Discussion}

In this survey study, conducted in schools of Sawangi and Salod, out of 300, 109 i.e $36 \%$ of students had habit of tobacco chewing. They consumed tobacco in different forms like supari-53\%, gutka-14\%, both $-12 \%$, tobacco- $11 \%$, pan masala-7 and kharra in $3 \%$. The reason for this liking is imitating others and more availability at near places, cheap and easy way to carry All 109 means 100\% addictive students had urge of tobacco. $67 \%$ of students were suffering from emotional 
symptoms like restlessness, nervousness, irritability, lack of concentration while $33 \%$ of students had no such symptoms. As impact of tobacco on their brain was so strong that even an idea of "no tobacco" causes them stress a lot. $52 \%$ of students consumed tobacco to stop physical and emotional problems while $48 \%$ of students did not consume to control emotional symptoms. $57 \%$ students were using tobacco when they planned not to use as they could not control withdrawal symptoms. $76 \%$ students had habit to have tobacco more frequently than they intended. $22 \%$ students had failed to stop tobacco habit. $20 \%$ students had periods when they consumed tobacco frequently for several days or more. $71 \%$ students had given up important activities so that they could consume it without disturbance while $29 \%$ students have not gave-up activities, might be due to start of the habit recently and fear of teachers if not involved. Thus, it shows that the students consuming tobacco products were having change in their psycho-social and behavioral attitude. They were more reluctant or stubborn, aggressive, impulsive and less concentrated in study than before addiction of tobacco. It mainly due to improper or less intake of diet and poor sleep. These symptoms appeared due to withdrawal nature when they wanted to give-up this habit but could not bear the severity of these features and some students started consumption again more frequently. They used to engage in consumption and its impact on their body and mind in such a way that they remain less interested in participation of extracurricular activities such as play or develop hobbies. Recent studies have found that tobacco use is increasing among school children in India and a sizeable proportion of them experiment with drugs quite early in life $(12,13)$.

The students especially girls who were not consuming tobacco products were not allowing addictive group of students to mix with them due to strong aroma of these products thereby addictive group were remain fell apart. Their academic performance was also reducing still they were reluctant rather helpless as could not stop this addiction on their own.

Some students have started tobacco consumption in the form of mainly Masala Supari pouch and Pan masala at early ages like eight or nine years of age because environmental factors (12-14) (parents, family members, neighbours, friends/peers were also consuming it) compelled them to initiate and reciprocate the habit. It was found in this survey study that there was parental neglect due to daily wages job and no elder person were looking after them. Parents were giving them some coins to spend as a pocket money before going to job as a token of love but they misused it in consumption of tobacco products and used to ask parents money to purchase and fulfill addiction. Similar study done by Surekha Kishore (6) also concluded the peer group influence was the reason for initiating this habit in majority of users.

\section{Conclusion}

In this survey study, it was found that out of 300 students, 109 students $-36 \%$ were in habit of smokeless tobacco products consumption and no one was taking in smoke form of tobacco. Out of these $36 \%$ addictive students, psycho-social and behavioral impact was $67 \%$ which is much higher. They were fell apart from non-addictive students due to strong aroma of these products, also they were not actively taking part in other school activities due to lack of interest, zest and zeal. The habit- forming impact was so exaggerated that $82 \%$ students were tried to give-up this habit but not succeeded. The reason of early start of consumption was mainly environmental factors and parental neglect. Teachers and students were made aware regarding the side effects of tobacco products by power point presentations in school.

\section{Acknowledgement}

I would like to thank the University Datta Meghe Institute of Medical Sciences, Mahatma Gandhi Ayurved College and Research Centre, Salod, Wardha, Dept. of Kaumarbhritya, post graduating students of Kaumarbhritya, mainly teachers and students of ZP schools for giving me opportunity to conduct the study.

\section{References}

1. Pal R, Tsering D. Tobacco use in Indian high-school students. Int J Green Pharm. October, 2009; 3(4); 319-323

2. Naresh M, Viral S, Sudha Y. Study on Prevalence of Smoking and Tobacco Chewing among Adolescents in rural areas of Jamnagar District, Gujarat State. Journal of Medical Science Research. 30 September,2007; 1(1); 47-49

3. Shenoy R.P, Shenai P.K. Tobacco use among rural school children of 13-15 years' age group: A crosssectional study. Indian $\mathrm{J}$ Community Med. July,2005; 35(3); 433-435

4. Mukherjee K, Hadaye R. Gutka. Consumption and its Determinants among Secondary School Mate Students. International Journal of Community Medicine. July,2006; 31(3); 177

5. Global Youth Tobacco Survey Collaborating Group. Differences in worldwide tobacco use by gender: findings from the Global Youth Survey. J Sch Health. August, 2003; 73(6); 207-215

6. Kishore S, Gupta M, Mishra P. Tobacco use by school children in rural Wardha, Maharashtra, Indian J. Prev. Soc. Med. July,2013; 44; 3-4 http:// medind.nic.in/ibl/t13/i3/iblt13i3p171.pdf \#Dated 06-09-2019 Time 12:10 IST (7)

7. Reddy K.S, Gupta P.C.Tobacco control in India. Tobacco use in India. https://www.who.int/fctc/ $\begin{array}{llllllllll}r & \mathrm{e} & \mathrm{p} & \mathrm{o} & \mathrm{r} & \mathrm{t} & \mathrm{i} & \mathrm{n} & \mathrm{g} & /\end{array}$ Annex6_Report_on_Tobacco_Control_in_India_20 04.pdf \#Dated 06-09-2019 Time 17:37 $\overline{\mathrm{IST}}$

8. Gupta P. C, The Public health impact of tobacco dependence. Current Science. 10 September,2001; 81(5); 475-481 
9. https://www.paho.org/hq/index.php? option $=$ com_content\&view=article\&id=13432:gyts \&Itemid=42359\&lang=en \#dated 07-09-2019 Time 13.24 IST

10. Global Youth Tobacco Survey collaborative group by $\mathrm{CDC}$ and WHO. Core Questionnaire with optional questions, Version1.2, (2014), Atlanta G A: Centers for Disease Control and Prevention, Smokeless tobacco module, school policy questionnaire

11. Etter J F, Houezec J L, Perneger T V. A SelfAdministered Questionnaire to Measure Dependence on Cigarettes: The Cigarette
D e p e n d e n c e
$\mathrm{S}$ c a $1 \mathrm{e}$
$\left(\begin{array}{llll}2 & 0 & 0 & 3\end{array}\right)$, Neuropsychopharmacology, volume 28, pages359370

12. NIDA National Institute on Drug Abuse www.drugabuse.gov/.tobacco-nicotine \#Dated 13-09-2019 Time 17:24 IST

13. https://www.cdc.gov/fact_sheets Smokeless tobacco: health effects \#Dated 14-9-2019 Time 16:20 IST

14. https://www.ncbi.nlm.nih.gov: A vision for the future the global tobacco epidemic, 2010 \#Dated 14-09-2019 Time 13:12 IST 